AKRUAL 2 (2) (2011): 109-135 $e$-ISSN: 2502-6380

\title{
AKRUAL
}

Jurnal Akuntansi

http://fe.unesa.ac.id/ojs/index.php/akrl

\section{CREATIVE ACCOUNTING: Apakah Suatu Tindakan Ilegal?}

\author{
MF. Arrozi Adhikara \\ Fakultas Ekonomi Universitas Esa Unggul, Jakarta \\ Email: arrozi@esaunggul.ac.id \\ Artikel diterima: 25 Januari 2011 \\ Terakhir direvisi: 2 Maret 2011
}

\begin{abstract}
This paper aims to explore the environment and the implementation of creative accounting events related to the context of ethical behavior and find solutions and ways to deal with matters creative accounting. Exploration carried out related to the definition of creative accounting, creative accounting in nature, ethics, reason for doing creative accounting practices, process behavior in creative accounting, as well as some summary results of empirical research about the events of creative accounting. Recent findings in this paper is to provide solutions and ways to prevent and solve problems in creative accounting accounting practices.
\end{abstract}

Keywords: Creative accounting, behaviour process, solution.

\section{PENDAHULUAN}

\section{Latar Belakang}

Isu creative accounting menjadi pusat perhatian terkait dengan adanya booming runtuhnya perusahaan-perusahaan terkemuka terkait dengan adanya skandal fraud (kecurangan), manipulasi laporan keuangan, kosmetika akuntansi, earning management, dan penolakan laporan keuangan. Akibatnya, menempatkan kepercayaan public dan users / pengguna pada laporan keuangan sebagai hasil profesionalisme akuntan semakin memudar. Titik awal memudarnya kepercayaan tersebut bermula pada Kasus Enron, Worldcom, Global Crossing, HIH, Tyco, kasus Bank Lippo, Kasus PT. Citra Marga Nusapala Persada, Bank Duta, Xerox, PT Perusahaan Gas Negara, dan Merck yang berjatuhan satu - persatu. Disamping itu adanya sederet kecurangan pada sejumlah perusahaan seperti yang terjadi pada PT. Kimia Farma Tbk., kasus manipulasi dalam laporan keuangan yang dilakukan manajemen PT. Bank Lippo, ditambah dengan penolakan laporan keuangan PT. Telkom oleh SEC yang secara langsung maupun tidak langsung mengarah pada profesi akuntan dan semakin menambah daftar panjang ketidakpercayaan terhadap profesi akuntan.

Kejadian skandal keuangan, kegagalan perusahaan, manipulasi laporan keuangan, kesalahan pemeriksaan laporan keuangan, dan skandal akuntansi yang 
menyebabkan peminggiran good corporate governance serta rekayasa keuangan yang terjadi pada praktik bisnis di perusahaan bukan hanya masalah akuntan publik karena hal tersebut menyangkut pelaporan kegiatan perusahaan secara keseluruhan (financial reporting). Dalam masalah financial reporting ini, semua pihak terlibat didalamnya. Jadi masalah ini juga merupakan permasalahan akuntan manajemen, akuntan pendidik, dan juga masalah regulator. Bahkan setelah dilakukan berbagai studi penyebab berbagai permasalahan yang timbul di dunia akuntansi ini termasuk juga para bankir, analisis keuangan, serta berbagai pihak lain yang terlibat di pasar modal. Semuanya mempunyai peranan yang signifikan. Mengapa demikian? Karena biasanya aktivitas proses creative accounting tersebut diatas dilakukan secara berjamaah karena prosesnya sangat kompleks dan prosesnya akan melibatkan berbagai pihak terkait.

Implikasi kejadian ini mengarah pada suatu pertanyaan, “ Apakah Laporan Keuangan masih bisa dipercaya? ". Kejadian besar diatas menyebabkan timbulnya keraguan yang besar atas the soundness of financial reporting system dan menimbulkan kerugian yang besar bagi investor, karyawan, kreditor, dan stakeholder lainnya. Akibatnya, pihak users (pengguna) mendapatkan informasi yang salah atas kondisi perusahaan karena terdapat upaya penyembunyian informasi yang relevan dan menggambarkan posisi keuangan yang salah. Sehingga mengakibatkan user mengambil suatu analisa dan keputusan yang salah. Akuntansi sebagai ilmu rekayasa (engineering) memberikan peluang dan inovasi bagi akuntan di perusahaan untuk melakukan pilihan dari berbagai alternatif metode akuntansi yang dapat digunakan dalam praktek-praktek akuntansi di perusahaan karena standar akuntansi telah menyediakan berbagai macam alternatif pilihan tersebut. Sehingga creative accounting bagi akuntan merupakan interpretasi dalam mengambil keuntungan atas peristiwa yang tidak diatur oleh standar akuntansi dan akuntan mengambil suatu keuntungan yang dengan cara melakukan penyembunyian atas transaksi tertentu.

Selanjutnya, untuk memahami bagaimana proses creative accounting bekerja, paper ini menguraikan dan memberikan alur sistematika berikut ini: Pertama, eksplorasi paper dilakukan terkait dengan nature dalam creative accounting. Kedua, behaviour creative accounting dengan contoh kasus yang terjadi pada PT Kimia Farma, Tbk (PT KAEF). Ketiga, alasan perilaku creative accounting dengan kasus yang terjadi dalam praktik di lapangan. Keempat, etika dalam creative accounting. Kelima, temuan akhir dalam paper ini adalah bagaimana melakukan upaya solusi untuk menangani masalah creative accounting dalam praktek-praktek akuntansi.

\section{KAJIAN PUSTAKA}

\section{Nature Creative Accounting}

Creative accounting adalah sebuah proses dimana beberapa pihak menggunakan kemampuan pemahaman pengetahuan akuntansi (termasuk didalamnya standar, teknik, prosedur, dsb.) dan menggunakannya untuk memanipulasi pelaporan keuangan (Amat, Blake dan Dowd, 1999). Sedangkan menurut Naser (1993) mendefinisikan creative accounting sebagai suatu proses manipulasi figur akuntansi 
dalam pengambilan keuntungan dari kelemahan peraturan akuntansi dan pemilihan dari pengukuran serta pengungkapan praktek-praktek didalamnya untuk merubah laporan keuangan dari apa yang harus disajikan. Pandangan tersebut dapat diartikan bahwa creative accounting meliputi proses transformasi rekening-rekening keuangan dalam laporan keuangan dengan menggunakan alternatif pilihan metoda akuntansi dari berbagai macam alternatif pilihan kebijakan akuntansi melalui mekanisme estimasi, artificial, dan prediksi dengan cara merekayasa dan manipulasi, serta implementasi pelaksanaannya yang diijinkan melalui peraturan akuntansi. Proses transformasi memberikan keleluasaan kepada pihak manajemen dalam memilih kebijakan akuntansi yang dilakukan dengan melihat suatu celah dalam peraturan akuntansi sebagai suatu kelemahan yang dapat dimanfaatkan untuk dipilih sebagai alternatif dari berbagai alternatif-alternatif pilihan yang dapat diambil sebagai salah satu kebijakan dalam mekanisme penyusunan dan pelaporan keuangan.

Creative accounting bukan merupakan suatu hal baru, dan timbulnya proses creative accounting ini dipicu oleh tekanan bahwa suatu badan usaha merasa harus berada dalam posisi laba untuk menarik investor dan kreditor maupun sumber daya. Karena adanya tekanan tersebut, manajemen dapat membuat suatu tindakan yang mengarah pada perilaku oportunistik yaitu tindakan untuk mempercantik laporan keuangan yang disebut dengan kosmetika akuntansi. Manajemen mempunyai perilaku oportunistik terhadap laporan keuangan dalam bentuk tindakan pemilihan accounting policy, manajemen laba (earning management), manipulasi laporan keuangan, serta penipuan atau kecurangan pada praktik akuntansi.

\section{Earnings Management}

Dalam perspektif earnings management, perusahaan melakukan intervensi dengan tujuan mendapatkan private gain dalam proses pelaporan keuangan eksternal. Sasarannya adalah memaksimalkan kompensasi serta menghindari pemutusan perjanjian utang dari utang obligasi yang akan menghalangi pembayaran deviden karena perusahaan yang mempunyai masalah keuangan akan menggunakan kebijakan akrual untuk meningkatkan laba untuk menghindari pelanggaran kontrak hutang. Dari sudut income smoothing, manajemen berusaha mencari income yang smooth sepanjang waktu sehingga earning stabil dengan variansi yang semakin kecil antar tahun sehingga penilaian perusahaan akan tinggi. Prosesnya melalui pemilihan metode alokasi serta klasifikasi smoothing antara income dari aktivitas operasi atau aktivitas non operasi. Implikasinya bagi perusahaan adalah membantu memprediksi aliran kas perusahaan di masa mendatang agar lebih baik, sedangkan bagi pasar modal yang naïf proses ini tidak dapat memecahkan keinginan user karena bantuan akuntansi tidak memberikan data secara akurat dan benar.

Tujuan akuntan melaksanakan earnings management dalam perusahaan adalah menggambarkan tindakan oportunis untuk memaksimumkan utilitasnya dalam menghadapi kontrak kompensasi, kontrak utang, dan political costs. Manajer menghendaki bonus atas kinerja yang telah dilakukannya kepada perusahaan. Kinerja yang dihasilkan tersebut terkadang belum tercapai sesuai dengan apa yang dimaui 
oleh perusahaan, dan perusahaan akan memonitor serta mengevaluasi hasil yang dicapai tersebut. Menyikapi kondisi tersebut, manajer akan berusaha untuk menampilkan secara cantik bentuk laporan keuangan dengan penyajian yang menarik dalam menunjukkan kinerjanya lewat laba yang bagus melalui setting laba yang terintegrasi dalam beberapa tahun yang akan datang, serta mengatur bagaimana laba yang terkomprehensif untuk beberapa tahun menghasilkan peningkatan yang signifikan. Untuk pencapaian tersebut, manajer akan bersikap fleksibel dan mempunyai pertimbangan untuk melindungi dirinya dan perusahaan dalam mengantisipasi kejadian-kejadian yang tidak terduga untuk keuntungan pihak-pihak yang terlibat dalam kontrak.

Proses earnings management oleh akuntan manajemen akan memberikan perilaku oportunistik bagi dirinya dan manajemen. Salah satu tujuannya adalah pengakuan kinerja akuntan yang tercapai dan memberikan implikasi bagi kinerja perusahaan secara keseluruhan. Mekanisme ini membuka suatu cakrawala bagi pengguna untuk bertanya, bagaimana cara melakukan earnings management? Sehingga terlihat wahana perspektif oportunistic perilaku akuntan melakukan mekanisme earnings management. Earnings management dinyatakan oleh Levit (1998) mendefinisikan earnings management sebagai tindakan yang dilakukan manajemen yang laporan laba cenderung menghasilkan lebih merefleksikan kepentingan manajemen daripada gambaran kinerja perusahaan yang sesungguhnya. Dalam definisi terkandung makna bahwa adanya earnings management dapat menyebabkan kinerja riil suatu perusahaan tidak kelihatan. Healy and Wahlen (1998) menyatakan bahwa earnings management terjadi pada saat manajer menggunakan pertimbangan dalam penyajian laporan keuangan dan pencatatan transaksi untuk merubah laporan keuangan, sehingga menyesatkan stakeholders tentang kinerja perusahaan atau untuk mempengaruhi hasil yang berhubungan dengan kontrak yang tergantung pada angka akuntansi yang dilaporkan. Definisi ini menyatakan bahwa earnings management adalah merupakan suatu tindakan yang dapat menyesatkan stakeholders. Sementara Schipper (1989) mendefinisikan earnings management sebagai intervensi dalam proses pelaporan keuangan kepada pihak eksternal yang bertujuan untuk memperoleh keuntungan pribadi untuk stockholder atau manajer.

Scott (2000) membagi cara pemahaman atas manajemen laba menjadi dua. Pertama, melihatnya sebagai perilaku oportunistik manajer untuk memaksimumkan utilitasnya dalam menghadapi kontrak kompensasi, kontrak utang dan political costs (oportunistic earnings management). Kedua, dengan memandang manajemen laba dari perspektif efficient contracting (efficient earnings management), dimana manajemen laba memberi manajer suatu fleksibilitas untuk melindungi diri mereka dan perusahaan dalam mengantisipasi kejadian-kejadian yang tak terduga untuk keuntungan pihak-pihak yang terlibat dalam kontrak. Dengan demikian, manajer dapat mempengaruhi nilai pasar saham perusahaannya melalui manajemen laba, misalnya dengan membuat perataan laba (income smoothing) dan pertumbuhan laba sepanjang waktu. 
Definisi earnings management hampir sama juga diungkapkan oleh Schipper (1989) dalam Sutrisno (2002) yang menyatakan bahwa manajemen laba merupakan suatu intervensi dengan tujuan tertentu dalam proses pelaporan keuangan eksternal, untuk memperoleh beberapa keuntungan privat (sebagai lawan untuk memudahkan operasi yang netral dari proses tersebut). Menurut Assih dan Gudono (2000) mengartikan manajemen laba sebagai suatu proses yang dilakukan dengan sengaja dalam batasan General Accepted Accounting Principles (GAAP) untuk mengarah pada tingkatan laba yang dilaporkan.

Earnings management (manajemen laba) adalah campur tangan dalam proses pelaporan keuangan eksternal dengan tujuan untuk menguntungkan diri sendiri. Manajemen laba merupakan salah satu faktor yang dapat mengurangi kredibilitas laporan keuangan, manajemen laba menambah bias dalam laporan keuangan dan dapat mengganggu pemakai laporan keuangan yang mempercayai angka laba hasil rekayasa tersebut (Setiawati dan $\mathrm{Na}^{\prime} \mathrm{im}, 2000$ ). Manajemen laba merupakan area yang kontroversial dan penting dalam akuntansi keuangan. Beberapa pihak yang berpendapat bahwa manajemen laba merupakan perilaku yang tidak dapat diterima, mempunyai alasan bahwa manajemen laba berarti suatu pengurangan dalam keandalan informasi laporan keuangan. Investor mungkin tdak menerima informasi yang cukup akurat mengenai laba untuk mengevaluasi return dan risiko portofolionya (Ashari dkk, 1994) dalam Assih (2004). Magnan dan Cormier dalam Gumanti (2000) menyatakan bahwa ada tiga sasaran yang dicapai oleh manajer sehubungan dengan earnings management yaitu meminimalisasi biaya politis (political cost minimization), maksimalisasi kesejahteraan manajer (manager wealth maximization) dan minimalisasi biaya finansial (minimization of financial costs). Menurutnya jelas hal ini menunjukkan bahwa sasaran dari earnings management adalah cukup komprehensif, yaitu mencakup banyak aspek dalam perusahaan baik demi kepentingan pribadi manajer maupun secara keseluruhan.

Pemikiran tentang earnings management memang menimbulkan banyak perbedaan pendapat. Menurut Gumanti (2000) earnings management sangat tergantung dari sisi mana kita memandangnya. Konsep good corporate governance dengan prinsip-prinsip transparansi, akuntabilitas, keadilan dan responsibilitas, mempunyai tujuan meningkatkan kepercayaan bagi investor dalam melakukan investasi (OECD, 2004), adanya earnings management merupakan tindakan yang menyesatkan pemakai laporan keuangan dengan menyajikan informasi yang tidak akurat, dan bahkan kadang merupakan penyebab terjadinya tindakan ilegal, misalnya penyajian laporan keuangan yang terdistorsi atau tidak sesuai dengan keadaaan sebenarnya. Dipandang dari sudut etika, tindakan ini berarti pelanggaran terhadap kepercayaan masyarakat (Levitt, 1998). Sudut pandang manajer terhadap earnings management yang mementingkan laba jangka pendek menunjukkan bahwa orientasi keuntungan perusahaan masih pada kesejahteraan stockholders bukan pada stakeholders.

Earnings management muncul atau dilakukan oleh manajer atau pembuat laporan keuangan dalam proses pelaporan keuangan suatu organisasi karena mereka 
mengharapkan suatu manfaat dari tindakan yang dilakukan. Latar belakang dilakukan earnings management ini adalah konsekuensi dari teori agensi yang memunculkan masalah agensi, adanya asimentri informasi dan fleksibilitas dalam pemilihan kebijakan akuntansi. Adanya asimetri informasi memberikan kontribusi terhadap tindakan earnings management. Laporan keuangan yang seyogyanya digunakan untuk meminimalkan konflik antara principals dan agent (Jensen dan Meckling, 1976) merupakan sarana untuk berlangsungnya earnings management. Laporan keuangan merupakan suatu laporan yang disajikan oleh manajemen, dalam penyajian laporan keuangan manajemen mempunyai informasi yang lebih banyak dibandingkan oleh pemilik itu sendiri. Secara teoritis kondisi ini menjadi pendorong dan memotivasi manajer untuk bersikap oportunis, yaitu berusaha memaksimalkan kesejahteraaan sendiri dengan melakukan earnings management pada saat pelaporan kinerja perusahaaan.

Adanya fleksibilitas pemilihan metode akuntansi dalam pembuatan laporan keuangan mengadung banyak asumsi, penilaian (judgement) serta pilihan untuk menentukan kebijakan akuntansi, adanya keleluasaan manajer untuk memanipulasi laporan keuangan, seperti yang dinyatakan oleh Levitt (1998) bahwa manajer akan mengeksploitasi adanya fleksibilitas yang ditetapkan dalam standart untuk melakukan earnings management. Tindakan earnings management dapat merugikan dapat diminimalisasi melalui suatu mekanisme monitoring yang bertujuan untuk menyelaraskan (alignment) berbagai kepentingan, pertama dengan memperbesar kepemilikan saham perusahaan oleh manajemen (managerial ownership) (Jensen dan Meckling, 1976) sehingga kepentingan pemilik atau pemegang saham dapat disejajarkan dengan kepentingan manajer; kedua, dengan kepemilikan saham oleh institusional, (Rajgofal et al., 1999) menyatakan bahwa investor institusional merupakan pihak yang memonitor agen dengan kepemilikan yang besar; ketiga melalui monitoring oleh dewan komisaris (Beasley, 1996) dan komite audit (Klein, 2002a).

Earnings management muncul diakibatkan karena informasi tentang laba yang merupakan sesuatu yang dipertimbangkan oleh investor dalam melakukan keputusan investasinya. Sejalan dengan penelitian yang dilakukan oleh Ball dan Brown (1968), menyatakan bahwa terdapat reaksi investor terhadap pengumuman laba kwartalan ataupun tahunan. Reaksi tersebut dapat tercermin dari naik turunnya harga saham dan volume perdagangan disekitar tanggal pengumuman. Penelitian lain yang memberikan hasil yang berbeda dalam menunjukkan pengaruh informasi tentang laba terhadap pengambilan keputusan investor dilakukan oleh Lako (2003). Penelitiannya menyimpulkan bahwa tidak terdapat perbedaan reaksi investor yang signifikan terhadap pengumuman laba baik laba perusahaan tersebut positif maupun negatif, sehingga berapapun laba yang disajikan tidak menjadi pertimbangan investor. Hal ini dapat muncul disebabkan karena para investor yang menjadi sampel adalah investor yang mempunyai karakteristik naive investor, dimana pengambilan keputusan investasi mereka lebih mengandalkan pada intuisi atau mengikuti pola 
portofolio tertentu bukan berdasarkan pada analisis fundamental kinerja laporan keuangan.

Pendapat yang sama di kemukakan oleh Foster (1986) menyatakan satu faktor yang mempengaruhi reaksi investor terhadap informasi laba adalah kredibilitas sumber informasi. Semakin kredibel suatu sumber informasi maka semakin besar implikasi terhadap informasi tersebut. Hal ini menunjukkan bahwa earnings management akan direspon oleh investor dengan berbagai sikap, untuk investor yang memfokuskan hanya informasi laba maka ada kemungkinan laba yang disajikan akan mendorong minat investor untuk mengambil keputusan berinvestasi tetapi apabila investor merupakan investor yang sophisticated dalam arti pengambilan keputusan dilakukan analis yang memadai sehingga dapat mengevaluasi kelayakan dari penyajian informasi tersebut, maka adanya earnings management tidak akan mendapat respon positif.

Pola manajemen laba menurut Scott (2000) dapat dilakukan dengan cara:

a. Taking a Bath

Pola ini terjadi pada saat reorganisasi termasuk pengangkatan CEO baru dengan melaporkan kerugian dalam jumlah besar. Tindakan ini diharapkan dapat meningkatkan laba di masa datang.

b. Income Minimization

Pola ini dilakukan pada saat perusahaan mengalami tingkat profitabilitas yang tinggi sehingga jika laba pada periode mendatang diperkirakan turun drastis dapat diatasi dengan mengambil laba periode sebelumnya.

c. Income Maximization

Pola ini dilakukan pada saat laba menurun. Tindakan atas income maximization bertujuan untuk melaporkan net income yang tinggi untuk tujuan bonus yang lebih besar. Pola ini dilakukan oleh perusahaan yang melakukan pelanggaran perjanjian hutang.

d. Income Smoothing

Pola ini dilakukan perusahaan dengan cara meratakan laba yang dilaporkan sehingga dapat mengurangi fluktuasi laba yang terlalu besar karena pada umumnya investor lebih menyukai laba yang relatif stabil.

\section{Behaviour Creative Accounting}

Creative accounting bagi akuntan manajemen adalah tempat untuk melakukan ekspresi pengetahuan akuntansi dan bertindak sesuai dengan preferensinya dalam praktek akuntansi. Motivasinya adalah materialisme sebagai pendorong besar melakukan creative accounting, sehingga untuk pencapaian ini, akuntan manajemen melakukan intervensi pada standar akuntansi yang berlaku serta berupaya mencari loophole dari standar akuntansi untuk diimplementasikan pada praktek akuntansi di lingkungan perusahaan. Salah satu wujud implementasinya adalah proses earning management. 
Untuk lebih jelasnya, berikut ini contoh kejadian praktek creative accounting dan perilaku yang menyertainya oleh akuntan untuk melakukan "earning management” dalam masalah kasus PT Kimia Farma, Tbk (PT KAEF).

PT Kimia Farma Tbk. (PT KAEF), merupakan salah satu produsen obatobatan milik pemerintah di Indonesia. Tujuan perusahaan sebagai badan usaha tidak berbeda dengan badan usaha lainnya, yaitu mencari laba sebesar-besarnya. Pelaporan keuangan pada tanggal 31 Desember 2001, menunjukkan adanya laba bersih sebesar Rp 132 milyar, dan laporan keuangan tersebut di audit oleh Hans Tuanakotta \& Mustofa (HTM). Akan tetapi, Kementrian BUMN dan Bapepam menilai bahwa laba bersih tersebut terlalu besar dan mengandung unsur rekayasa. Setelah dilakukan audit ulang, pada tanggal 3 Oktober 2002 laporan keuangan PT. KAEF tahun 2001 disajikan kembali (restated). Hal ini disebabkan telah ditemukan kesalahan yang cukup mendasar. Pada laporan keuangan restated, laba yang disajikan hanya sebesar $\mathrm{Rp}$ 99,56 miliar, atau lebih rendah sebesar $\mathrm{Rp} 32,6$ milyar, atau 24,7\% dari laba awal yang dilaporkan.

Kesalahan itu timbul dari :

a. Kesalahan penyajian dalam laporan keuangan PT KAEF. Sehingga dampak kesalahan tersebut mengakibatkan overstated laba pada laba bersih untuk tahun yang berakhir 31 Desember 2001 sebesar Rp 32,6 miliar yang merupakan 2,3\% dari penjualan dan 24,7\% dari laba bersih PT KAEF.

b. Kesalahan tersebut terdapat pada unit-unit sebagai berikut:

1. Unit Industri Bahan Baku: Kesalahan berupa overstated penjualan sebesar Rp 2,7 Miliar.

2. Unit Logistik Sentral: Kesalahan berupa overstated persediaan barang sebesar Rp 23,9 Miliar.

3. Unit Pedagang Besar Farmasi (PBF): Kesalahan berupa overstated persediaan barang sebesar Rp 8,1 Miliar dan Kesalahan berupa overstated penjualan sebesar Rp 10,7 Miliar.

c. Bahwa kesalahan penyajian tersebut, dilakukan oleh Direksi periode 1998-Juni 2002 dengan cara:

1. Membuat 2 (dua) daftar harga persediaan (master prices) yang berbeda masing-masing diterbitkan pada tanggal 1 Pebruari 2002 dan 3 Pebruari 2002, dimana keduanya merupakan master prices yang telah diotorisasi oleh pihak yang berwenang yaitu Direktur Produksi PT KAEF. Master prices per 3 Pebruari 2002 merupakan master prices yang telah disesuaikan nilainya (penggelembungan) dan dijadikan dasar sebagai penentuan nilai persediaan pada unit distribusi PT KAEF per 31 Desember 2001. 
2. Melakukan pencatatan ganda atas penjualan pada unit PBF dan unit Bahan Baku. Pencatatan ganda tersebut dilakukan pada unitunit yang tidak disampling oleh Akuntan.

Mencermati kasus PT KAEF, penulis menyikapi bahwa manajemen PT KAEF telah melakukan creative accounting dengan pendekatan earning management yang illegal. Laba merupakan indikator dan motivasi dengan unsur utamanya adalah materialisme. Sehingga, untuk mencapai orientasi laba tersebut sangat jamak bagi akuntan PT KAEF mengambil tindakan dan berupaya memaksimalkan kreativitasnya melalui proses akuntansi. Caranya, akuntan PT KAEF melakukan praktek earning management dengan melakukan manipulasi pada berbagai prosedur akuntansi di bagian persediaan, produksi, penjualan, keuangan dan metode akuntansinya, serta mengeksplorasi unsur-unsur pembentuk laba melalui pengakuan transaksi, penilaian accounts, pengukuran accounts, serta penyajian dan pelaporan accounts dalam laporan keuangan. Perlakuan akuntansi diatas dilakukan treatment dalam rangka pencapaian target laba yang diinginkan oleh semua pihak, yaitu stakeholder. Proses ini memberikan tindakan-tindakan bagi akuntan PT KAEF untuk melakukan berbagai macam upaya dalam rangka memenuhi target orientasi laba yang dicanangkan oleh manajemen PT KAEF. Hal tersebut bagi akuntan PT KAEF adalah lazim, karena akuntan manajemen adalah sebagai penerima, pengolah, penguasa dan pentransfer informasi di perusahaan.

Orientasi laba mempunyai implikasi penting. Pertama, bagi akuntan PT $\mathrm{KAEF}$, adalah sebagai manifestasi performance selama satu periode untuk menunjukkan prestasi dan mendapatkan bonus dari PT KAEF. Kedua, bagi manajemen PT KAEF, sebagai pertanggungjawaban kinerja perusahaan kepada stakeholder, serta memberikan makna penting bagi investor dan calon investor potensial di pasar modal untuk melihat prospek perusahaan di masa datang serta untuk menaikkan value of the firm melalui harga saham yang liquid.

Unsur hakiki creative accounting tidak terlepas dari aspek perilaku akuntan PT KAEF yang berproses dalam dirinya untuk melaksanakan earning management. Perilaku utama adalah oportunistik. Dalam kasus PT KAEF diatas, akuntan yang terlibat dalam proses penyusunan laporan keuangan memiliki kecenderungan dan motif untuk memaksimalkan utilitasnya melalui pengalokasian sumberdaya persediaan dalam proses pembelian, produksi, dan penjualan. Perilaku ini memberikan sikap oportunist bagi akuntan PT KAEF untuk memunculkan kesempatan dan peluang melakukan treatment, artificial transaksi, perekayasaaan, dan manipulasi pada prosedur akuntansi di bagian pembelian, persediaan, produksi, penjualan, keuangan dan metode akuntansinya, serta mengeksplorasi secara luas transaksi yang berhubungan dengan rekening penjualan dan persediaan pada pengakuan transaksi, penilaian accounts, pengukuran accounts, serta penyajian dan pelaporan accounts dalam laporan keuangan. Tujuannya dapat dilihat dua sudut pandang yang saling mengisi, yaitu dari sudut pandang akuntan adalah memenuhi kinerja dan memanfaatkan posisinya untuk mendapatkan bonus yang menarik. Dari 
sudut pandang manajemen PT KAEF adalah karena modal PT KAEF berasal dari pihak luar (investor dan kreditor), maka pihak luar harus dipenuhi kontraknya melalui pertanggunggungjawaban dalam laporan keuangan. Salah satu klausul dalam kontrak tersebut adalah pihak PT KAEF harus menunjukkan laba yang prospektif, pemenuhan rasio Debt Equity Ratio (DER), dan modal kerja yang liquid.

Salah satu unsur attitude yang terkait dengan creative accounting adalah komitmen, artinya terdapat dorongan dari akuntan PT KAEF untuk berbuat sesuatu agar dapat menunjang keberhasilan manajemen PT KAEF sesuai dengan tujuan manajemen PT KAEF. Bentuk komitmen akuntan PT KAEF adalah bagaimana usaha akuntan kepada manajemen PT KAEF untuk mencapai laba yang diinginkan sehingga stakeholder akan merasa satisfaction dan expectacion mereka terpenuhi. Hal tersebut penting karena adanya ikatan kontrak antara agent dengan principal, dan sangat beralasan bagi akuntan PT KAEF menggunakan kebijakan akrual pada penilaian persediaan dan transaksi artificial pada penjualan untuk meningkatkan laba dalam rangka menghindari konflik kepentingan dengan stakeholders. Adanya motif orientasi laba, maka komitmen diatas menunjukkan keyakinan dan dukungan yang kuat terhadap nilai dan sasaran yang ingin dicapai manajemen PT KAEF. Komitmen tumbuh pada akuntan PT KAEF dikarenakan akuntan memiliki ikatan emosional terhadap perusahaan yang meliputi dukungan moral, penerimaan nilai-nilai yang ada dalam perusahaan, serta tekad dalam diri akuntan untuk pengabdian kepada PT KAEF.

Unsur affective lain adalah partisipasi. Partisipasi dalam creative accounting menunjukkan keterlibatan akuntan dalam proses penyusunan dan pelaporan keuangan. Sehingga dengan keterlibatan ini, akuntan berapresiasi dalam mempersiapkan proses penyusunan laporan keuangan. Tugas akuntan lebih mendasarkan kebijakan akuntansinya pada standar akuntansi yang ditentukan dan mempengaruhi kebijakan akuntansi pada masing-masing elemen laporan keuangan. Dalam kasus PT KAEF tersebut diatas, unsur utama creative accounting pada aspek penilaian, pengukuran, dan penyajian rekening persediaan dan penjualan.

Partisipasi akuntan PT KAEF adalah bagaimana melakukan pencarian dan penentuan metode akuntansi dari berbagai alternatif metode akuntansi yang disediakan oleh standar akuntansi pada rekening persediaan dan penjualan. Metode akuntansi yang tersedia untuk persediaan dan penjualan diantaranya adalah at cost, at sale, at market, lowcom, fair value, dsb. Akuntan akan menilai setiap metode tersebut untuk menaksir rekening tersebut terdapat unsur kelemahan dan kekuatannya. Sehingga pada saat penyajian laporan keuangan, persediaan seharusnya dinilai per tanggal 31 Desember 2001 tetapi menggunakan dasar penilaian persediaan tanggal 3 Februari 2002 dan ini kesalahan dalam bentuk overstate pada rekening persediaan dan penjualan diatas. Kalau persediaan barang dinilai tinggi pada tanggal 31 desember 2001 akan memberikan implikasi bagi rekening Penjualan, Harga Pokok Penjualan, dan Laba Bersih. Artificial bagi rekening penjualan adalah kalau persediaan dibuat nilai penggelembungan, maka harga jual barang akan mempunyai nilai prosentase mark up tertentu diatas nilai persediaan yang digelembungkan. 
Sehingga nilai penjualan mengandung nilai yang tidak semestinya. Artificial bagi harga pokok penjualan adalah semakin besar persediaan barang akhir periode dengan nilai digelembungkan maka nilai harga pokok penjualan akan semakin rendah, sehingga pada saat penentuan laba maka mengandung nilai artificial bagi laba karena tidak mencerminkan nilai laba semestinya. Kalau nilai artificial dibuat pada accounts laporan keuangan maka kandungan informasi dalam laporan keuangan bersifat semu dan maya walaupun laporan keuangan tersebut memberikan penampilan yang cantik, menarik, dan apik. Ada suatu benang merah yang bisa ditarik dari perilaku disini, yaitu semakin tinggi tingkat partisipasi akuntan dalam proses keterlibatan penyusunan dan pelaporan keuangan maka semakin tinggi pula akuntan untuk mempengaruhi mekanisme pemilihan metode akuntansi sebagai kebijakan akuntansi perusahaan. Keterlibatan akuntan akan membuka peran akuntan dengan domain dan spektrum akuntansi yang luas.

Unsur cognitive disini adalah preferensi yaitu pilihan dan pengambilan keputusan yang mempunyai esensi rasional (Slovic, 1995). Artinya, akuntan menyusun pilihan yang memungkinkan dan membuat keputusan dalam memaksimalkan ukuran nilai subyektifitas atau kesejahteraan yang ditunjukkan oleh bentuk utility. Preferensi akuntan ditunjukkan melalui perilaku sebagai berikut, yaitu akuntan mampu memilih berbagai alternatif metode akuntansi dengan menyusun peringkat dari berbagai alternatif metode akuntansi sehingga bisa diambil keputusan, setiap peringkat alternatif bersifat transitif, akuntan memperhatikan risiko alternatif metode akuntansi yang dipertimbangkan, dan akuntan mampu menentukan certainty equivalent dari setiap metode akuntansi yang tidak pasti.

Akuntan memilih dan mengambil keputusan dengan melakukan peran artificial dan rekayasa dalam penentuan persediaan di Neraca per 31 Desember 2001 serta Penjualan dan Harga Pokok Penjualan di Laba Rugi untuk periode yang berakhir 31 Desember 2001 berdasarkan nilai yang disesuaikan (master prices) pertanggal 3 Februari 2002. Hal ini mengindikasikan bahwa akuntan PT KAEF mampu memilih alternatif metode akuntansi dari penilaian persediaan (seperti at cost, at sale, at market, lowcom, fair value, nilai yang disesuaikan, dsb.) dengan menyusun peringkat dari penilaian persediaan tersebut sehingga bisa diambil keputusan dengan menentukan penilaian pada nilai yang disesuaikan (master prices); setiap peringkat alternatif bersifat transitif (nilai yang disesuaikan > at cost > at sale > at market > lowcom > fair value); akuntan memperhatikan risiko alternatif metode akuntansi yang dipertimbangkan, artinya akuntan manajemen PT KAEF dapat melihat implikasi dan konsekwensi yang akan diterima dengan memilih metode penilaian persediaan pada nilai yang disesuaikan; serta akuntan mampu menentukan certainty equivalent dari setiap metode akuntansi yang tidak pasti, artinya dengan memilih dan memutuskan penilaian persediaan berdasarkan nilai yang disesuaiakan per 3 februari 2002 akuntan PT KAEF mampu menentukan nilai yang pasti dari persediaan untuk penentuan penilaian transaksi persediaan yang belum terjadi, meskipun hal ini mendasarkan pada prospektif dari suatu laporan. 
Preferensi akuntan PT KAEF adalah merwujudkan penyajian persediaan dengan tidak mendasarkan nilainya dari historis transaksi pembelian berdasarkan nilai at cost untuk rentang waktu sepanjang 1 Januari 2001 sampai dengan 31 Desember 2001. Titik waktu yang dipakai untuk penilaian persediaan adalah bersifat historis atas dasar transaksi, sehingga penentuan arus persediaan baik dengan menggunakan LIFO atau FIFO atau Average akan tetap menggunakan nilai persediaan akhir pada rentang waktu tersebut. Akuntansi menginformasikan berdasarkan transaksi historis bukan prospektif. Artinya dalam laporan keuangan 31 Desember 2001 berisi informasi keuangan untuk kejadian-kejadian bisnis selama 1 periode dalam tahun 2001 dan bukan atas dasar kejadian masa datang (prospektif) yang sifat transaksinya belum terjadi. Hal ini menyalahi aturan kebijakan akuntansi yang terdapat dalam standar akuntansi. Implikasinya laporan keuangan PT KAEF adalah salah saji yang material dan sifatnya kriminal karena illegal.

Atas dasar kejadian yang terjadi, dapat disebutkan bahwa perlakuan creative accounting yang digunakan PT KAEF merupakan bagian dari 'accounting manipulation' yang terdiri dari 'earning management', 'income smoothing' dan 'creative accounting' itu sendiri. "Creative” disini tergantung kembali dari maksud dan tujuan yang akan dikembangkan oleh manajemen. Creative dikatakan ilegal apabila ternyata memang menyalahi prosedur atau perundang - undangan yang berlaku dengan memanfaatkan "LOOPHOLE" yang ada dalam peraturan itu sendiri. Maksudnya, memanfaatkan kelemahan peraturan, seperti membuat transaksi yang belum pernah ada dalam peraturan (ini juga bisa dikatakan sebagai creativity karena ternyata diundang - undang atau standar tidak dinyatakan perlakuannya) atau dengan cara memanfaatkan peraturan yang ada yang diperbolehkan untuk menghasilkan "KEUNTUNGAN ATAU KERUGIAN". Implikasinya, akuntan se"creative" mungkin menggunakan kemampuannya untuk menampilkan laporan keuangan dengan sangat cantik.

\section{Alasan Perilaku Creative Accounting}

Perilaku creative accounting oleh manajemen disadari peranannya dalam rangka memenuhi tujuan akhir, yaitu bagaimana menampilkan penyajian laporan keuangan dengan menghasilkan profit oriented. Tujuan ini disadari sebagai salah satu motivator untuk menuju sikap (attitude) pelaksanaan kreativitas perekayaan keuangan dalam perusahaan. Ada lima alasan motivasi lainnya yang mendasari perilaku dalam bercreative accounting beserta contohnya, yaitu:

Pertama, dari perspektif informasi menunjukkan suatu konflik yang diciptakan oleh asimetri informasi dan eksitensinya dalam struktur korporat yang kompleks antara hak istimewa manajemen dengan jauhnya stakeholders. Manejer memilih untuk mengeksploitasi posisi hak istimewanya karena laba perusahaan melalui pengelolaan pengungkapan pelaporan keuangan sesuai seleranya. Perspektif informasi mengasumsikan bahwa pengungkapan akuntansi mempunyai kandungan informasi yang memiliki nilai kepada stakeholders dalam penyediaan sinyal yang bermanfaat. Implikasinya, creative accounting bagi perusahaan memberikan pilihan 
untuk menginformasikan laporan keuangan kepada pengguna dengan berbagai versi. Terdapat suatu tindakan rekayasa yang bervariasi dan berbeda yang akan diperlakukan kepada masing-masing pihak. Kandungan informasi yang diberikan dari versi laporan keuangan memberikan suatu sinyal yang beragam dan berselera user. Creative accounting untuk user pemerintah akan berbeda dengan creative accounting bagi investor maupun kreditor karena kandungan informasi yang diberikan oleh laporan keuangan tersebut dihasilkan dari rekayasa dengan teknik yang berbeda. Hal tersebut ditunjukkan pada contoh kasus yang dialami oleh PT Bank Lippo, Tbk.

PT Bank Lippo, Tbk yang sedang mengikuti program rekapitalisasi, mempublikasikan laporan keuangan secara berbeda kepada publik yang berbeda dan terdapat unsur manipulasi atau kesengajaan untuk memberikan informasi yang menyesatkan kepada public. Berkaitan dengan laporan keuangan PT Bank Lippo Tbk per 30 September 2002 tersebut, BAPEPAM menemukan bahwa terdapat 3 (tiga) versi laporan keuangan, yang semuanya dinyatakan audited, yaitu:

1. Laporan Keuangan PT Bank Lippo Tbk per 30 September 2002 yang diiklankan di surat kabar pada tanggal 28 November 2002. Pemuatan iklan tersebut merupakan pelaksanaan kewajiban PT Bank Lippo Tbk atas ketentuan Bank Indonesia. Adapun materi atau informasi yang tercantum dalam iklan laporan keuangan tersebut antara lain adalah:

a. Adanya pernyataan Manajemen PT Bank Lippo Tbk bahwa laporan keuangan tersebut disusun berdasarkan Laporan Keuangan Konsolidasi yang telah diaudit oleh KAP Prasetio, Sarwoko \& Sandjaja (penanggung jawab Drs. Ruchjat Kosasih) dengan pendapat wajar tanpa pengecualian.

b. Penyajian dalam bentuk komparasi per 30 September 2002 ("Diaudit") dan per 30 September 2001 ("Tidak Diaudit").

c. Nilai Agunan Yang Diambil Alih ("AYDA") per 30 September 2002 sebesar Rp 2,393 triliun;

d. Total aktiva per 30 September 2002 sebesar Rp 24,185 triliun;

e. Laba tahun berjalan per 30 September 2002 sebesar Rp 98,77 miliar;

f. Rasio Kewajiban Modal Minimum Yang Tersedia sebesar $24,77 \%$.

2. Laporan Keuangan PT Bank Lippo Tbk per 30 September 2002 yang disampaikan ke BEJ pada tanggal 27 Desember 2002. Penyampaian laporan tersebut merupakan pemenuhan kewajiban PT Bank Lippo Tbk untuk menyampaikan Laporan Keuangan Triwulan ke-3. Adapun materi atau informasi yang tercantum dalam laporan keuangan tersebut antara lain adalah:

a. Pernyataan manajemen PT Bank Lippo Tbk bahwa laporan keuangan yang disampaikan adalah laporan keuangan "audited" 
yang tidak disertai dengan Laporan Auditor Independen yang berisi opini Akuntan Publik.

b. Penyajian dalam bentuk komparasi per 30 September 2002 ("audited") dan 30 September 2001 ("unaudited").

c. Nilai Agunan Yang Diambil Alih-bersih ("AYDA") per 30 September 2002 sebesar Rp 1,42 triliun;

d. Total aktiva per 30 September 2002 sebesar Rp 22,8 triliun;

e. Rugi bersih per 30 September 2002 sebesar Rp 1,273 triliun;

f. Rasio Kecukupan Modal sebesar 4,23\%.

3. Laporan Keuangan PT Bank Lippo Tbk per 30 September 2002 yang disampaikan oleh Akuntan Publik KAP Prasetio, Sarwoko \& Sandjaja kepada Manajemen PT Bank Lippo Tbk pada tanggal 6 Januari 2003. Adapun informasi yang tercantum dalam masing-masing laporan keuangan tersebut antara lain adalah sebagai berikut:

a. Laporan Auditor Independen yang berisi opini Akuntan Publik Drs. Ruchjat Kosasih dari KAP Prasetio, Sarwoko \& Sandjaja dengan pendapat Wajar Tanpa Pengecualian. Laporan Auditor Independen tersebut tertanggal 20 November 2002, kecuali untuk Catatan 40a tertanggal 22 November 2002 dan Catatan 40c tertanggal 16 Desember 2002.

b. Penyajian dalam bentuk komparasi per 30 September 2002, 31 Desember 2001 dan 31 Desember 2000.

c. Total aktiva per 30 September 2002 sebesar Rp 22,8 triliun;

d. Nilai Agunan Yang Diambil Alih-bersih ("AYDA") per 30 September 2002 sebesar Rp 1,42 triliun;

e. Rugi bersih per 30 September 2002 sebesar Rp 1,273 triliun;

f. Rasio Kecukupan Modal sebesar 4,23\%.

Alasan kedua adalah keberadaan pajak yang dipungut berdasarkan penghasilan (income). Keyakinan para pemegang saham dan pekerja bahwa manajemen mudah untuk melaporkan laba yang stabil serta harapan secara psikologis berkenaan terhadap kenaikan atau penurunan dalam penghasilan yang diantisipasi. Sebagai contoh, pelaporan laba stabil melalui earning management akan menghasilkan suatu prediksi tentang jumlah pajak yang akan dibayarkan tiap tahun dapat diestimasikan. Bagi manajemen, jumlah pajak tersebut akan memberikan penghematan pajak pendapatan bagi perusahaan. Implikasinya, perusahaan akan menerapkan tax planning yang merupakan kegiatan bersaudara dengan earning management. Hal tersebut ditunjukan pada kasus PT Sepatu Bata, Tbk dan PT Indosat, Tbk.

Contoh Kasus Positif pada PT Sepatu Bata Tbk dari catatan atas laporan keuangan yang tidak Diaudit pada periode 31 Maret 2005. 
Beban pajak kini ditetapkan berdasarkan taksiran laba kena pajak tahun berjalan. Pajak tangguhan dicatat dengan menggunakan metode kewajiban untuk semua perbedaan temporer yang timbul antara aktiva dan kewajiban berbasis fiskal dengan nilai tercatatnya menurut laporan keuangan. Tarif pajak saat ini digunakan untuk menentukan beban pajak tangguhan. Aktiva pajak tangguhan yang berhubungan dengan saldo rugi fiskal yang belum digunakan diakui apabila besar kemungkinannya bahwa jumlah laba fiskal di masa mendatang akan memadai untuk dikompensasi dengan saldo rugi fiskal yang belum digunakan. Koreksi terhadap kewajiban perpajakan diakui pada saat Surat Ketetapan Pajak diterima atau pada saat keputusan atas keberatan telah ditetapkan jika Perusahaan mengajukan keberatan.

Contoh Kasus Negatif pada PT Indosat Tbk telah melakukan hedging transaksi derivatif untuk menggembosi pendapatan perusahaan yang berakibat pada penurunan penerimaan negara dari pajak. Indosat dikatakan telah melakukan 17 transaksi kontrak swap valuta asing dan suku bunga senilai US\$275 juta yang membuat pendapatan perusahaan mengempis. Sejak 2004-2006, Indosat diduga mengalami kerugian sebesar Rp.653 miliar lebih. Laporan laba rugi konsolidasi badan menunjukkan pos rugi perubahan nilai wajar derivatif bersih yang menyebabkan perusahaan merugi pada 2004 (Rp.170,45 miliar), 2005 (Rp.44,20 miliar), dan 2006 (Rp.438,77 miliar). Kerugian tersebut memelorotkan penerimaan pajak sebesar Rp.323 miliar yang terdiri dari PPh Rp.196 miliar, dividen Rp.65 miliar, dan PPh Pasal 26 atas dividen investor asing Rp.62 miliar. Ada yang menduga bahwa transaksi lindung nilai (hedging) yang dilakukan Indosat sejatinya diarahkan untuk utang STT (Singapore Technologies Telemedia). Hal ini diduga semacam engineering berbentuk transfer pricing dari Indosat ke STT yang dilakukan Temasek. Terlepas dari beberapa dugaan tersebut, memang harus disadari bersama bahwa pada umumnya pajak masih dianggap beban yang mengurangi penghasilan dan daya belanja maka tidak semua perusahaan patuh membayar pajak. Mereka yang beroperasi dalam skala global lebih banyak punya pilihan, peluang, kesempatan, dan teknik serta rekayasa menghindari pajak (tax avoidance) dan menyelundup pajak (tax evation).

Alasan ketiga adalah adanya kesenjangan (gap) antara kinerja aktual perusahaan dengan harapan analis ketika transaksi pasar modal secara siginifikan diketahui. Untuk mengurangi gap dan risiko dari analis dan penilaian sekuritas maka income smoothing dilakukan dengan variasi untuk memanipulasi profit dan bersambung pada peramalan. Hal ini menimbulkan harapan (expectations). Sebagai contoh, proses income smoothing akan memberikan tindakan pilihan bagi manajer 
untuk membuat judgment (perkiraan) terhadap estimasi dan peramalan tingkat piutang tidak tertagih, estimasi kurun waktu depresiasi aktiva tetap, atau amortisasi aktiva tak berwujud, estimasi biaya garansi, dan lain-lain. Aplikasi teknik ini ditunjukkan pada kasus PT Sepatu Bata, Tbk dalam catatan atas laporan keuangan.

Contoh Kasus PT Sepatu Bata Tbk dari catatan atas laporan keuangan yang tidak diaudit pada periode 31 Maret 2005 tentang penggunaan estimasi untuk peramalan. Penyusunan laporan keuangan berdasarkan prinsip akuntansi yang berlaku umum mengharuskan manajemen untuk membuat estimasi dan asumsi yang mempengaruhi jumlah yang dilaporkan dalam laporan keuangan. Karena adanya ketidakpastian yang melekat dalam penetapan estimasi, maka jumlah sesungguhnya yang akan dilaporkan di masa mendatang mungkin berbeda dari jumlah yang diestimasi tersebut.

Alasan keempat adalah adanya konflik kepentingan antara manajer dengan pemilik. Pemilik adalah orang yang tetap menguasai pengendalian dari taruhan yang cukup besar dan oleh karena itu tidak tertarik dalam strategis ke luar untuk mengelola earnings. Konflik timbul karena masalah adu kepentingan di dalam organisasi. Manajer perusahaan memiliki tujuan personal yang bersaing dengan tujuan untuk memaksimimalisasi kesejahteraan pemegang saham. Ketika pemegang saham memberikan kewenangan kepada manajer untuk mengelola asset perusahaan, konflik kepentingan akan muncul antara dua kelompok tersebut.

Potensi konflik agensi muncul ketika manajer memiliki saham kurang dari 100 persen. Jika bentuk perusahaan adalah perorangan yang diatur oleh pemilik, owner-manager akan melakukan tindakan untuk memaksimalkan kesejahteraannya. Owner-manager akan mengukur utilitas dengan ukuran kesejahteraan pribadi. Jika owner-manager menjual kepemilikannya pada investor luar, konflik kepentingan, yang dikenal dengan istilah konflik agensi, akan muncul. Hal ini dikarenakan ownermanager tidak akan bekerja keras untuk memaksimalisasi kesejahteraan pemegang saham, sebab akibat penurunan hasil tidak sepenuhnya menjadi bebannya. Owner manager mungkin memutuskan untuk menggunakan sumber daya lebih banyak, sebab beberapa beban tersebut akan dipikul oleh investor luar.

Pada perusahaan yang mayoritas sahamnya diperdagangkan ke publik, konflik agensi sangat signifikan sebab manajer umumnya memiliki saham dalam persetase yang sedikit. Maksimalisasi kesejahteraan pemegang saham dapat mengalahkan tujuan manajerial lainnya. Sebagai contoh, manajer mungkin memiliki keinginan untuk memaksimalisasi ukuran perusahaan, seperti membuat perusahaan lebih cepat tumbuh dan besar, maka manajer akan meningkat statusnya, serta membuka kesempatan kenaikan gaji, jabatan dan bonus. Manajer diarahkan supaya bertindak untuk kepentingan terbaik pemegang saham melalui insentif, constraint, dan hukuman. Metode ini akan efektif jika pemegang saham secara langsung mengobservasi seluruh tindakan yang diambil oleh manajer. 
Kasus konflik keluarga Nyonya Meneer menunjukkan bahwa perusahaan keluarga memang rapuh. Rapuh tak hanya oleh hempasan perubahan lingkungan bisnis eksternal, tetapi lebih-lebih oleh konflik dan perpecahan dalam tubuh organisasi perusahaan. Tidak seperti perusahaan pada umumnya, perusahaan keluarga memang memiliki beberapa "handicap struktural" yang membuat pengelolaannya menjadi lebih pelik. Pertama, seperti kasus Nyonya Meneer, tingginya potensi konflik kepentingan antar anggota keluarga. Konflik antaranggota keluarga ini sering menyebabkan tingginya corporate politic dalam perusahaan, yang ujung-ujungnya berdampak tidak fokusnya perusahaan untuk membangun strategi, melakukan pengambilan keputusan, dan mengalokasi sumber daya. Kedua, menyangkut tetek bengek pengelolaan keluarga yang, dalam hal ini, merupakan salah satu stakeholder utama perusahaan mengingat posisinya sebagai pemilik. Berbagai isu yang menyangkut pengelolaan keluarga ini sangat beragam dan luas cakupannya, seperti pembagian "kekuasaan" di antara anggota keluarga pemilik, penentuan anggota keluarga yang akan duduk di dalam manajemen, membangun trust dan family bond, mengelola berbagai kepentingan yang bermain di antara keluarga yang terlibat di dalam perusahaan, menentukan garis besar kebijakan keluarga, menyatukan visi keluarga, mengelola konflik antarkeluarga, dan perencanaan suksesi dari satu generasi ke generasi berikutnya.

Alasan kelima adalah kosmetika akuntansi akan membantu menyajikan laporan keuangan menjadi cantik. Hal ini membantu untuk mempertahankan harga saham oleh pengurangan tingkat pinjaman, membuat tampilan perusahaan yang berkurang resikonya, dan menunjukkan kesenderungan trend profit yang baik. Tujuan ini akan membantu perusahaan untuk menaikkan modal dari pengeluaran saham baru, menawarkan kepemilikan saham dalam penawaran takeover, dan menolak takeover oleh perusahaan lain. Contoh, akuntan cenderung untuk melakukan manipulasi dalam pelaporan keuangan. Tindakan yang dilakukan supaya menunjukkan angka-angka dalam laporan keuangan adalah manipulasi dan memasukkan transaksi artificial ke dalam neraca maupun laba rugi serta memindahkan profits diantara periode akuntansi. Hal tersebut dicapai oleh pemasukan ke dalam dua atau banyak transaksi yang berhubungan dengan suatu kewajiban entitas. Contoh kasus Worldcom sebagai berikut:

Worldcom mengungkapkan profit sebesar USD 1,4 juta pada tahun 2001 dan bukan mencatat adanya kerugian. Hal ini terjadi karena Worldcom melakukan kapitalisasi biaya secara tidak benar. Worldcom memasukan biaya-biaya yang seharusnya dicatat sebagai beban operasi diakui ke dalam capital expenditure yang jumlahnya mencapai US\$ 3,8 miliar. Proses kapitalisasi oleh Worldcom menunjukkan perlakuan akuntansi sebagai berikut: [a] Worldcom mengeluarkan sejumlah biaya 
yang didalamnya termasuk biaya gaji dan upah pekerja serta biaya sambungan. [b] Biaya-biaya tersebut tidak dimasukkan dalam income statement tetapi dimasukkan dalam komponen balance sheet sebagai asset yang akan dikapitalisasi. Mengkapitalisasi biaya juga akan mempengaruhi beberapa item dari arus kas meskipun arus kas secara total (di luar pembayaran pajak) tidak berubah.

Dengan adanya kapitalisasi biaya, laba operasi menjadi lebih tinggi sehingga arus kas operasi akan naik karena dengan mencatat beban yang seharusnya diakui pada tahun terjadinya dengan mengkapitalisasi selama beberapa tahun, akan menyebabkan laba bersih lebih tinggi dari yang seharusnya dilaporkan. Di lain pihak, arus kas investasi terjadi penurunan karena biaya tersebut dianggap sebagai capital expenditure. Depresiasi juga akan meningkat karena adanya penambahan aktiva tetap.

Worldcom melaporkan kas dari operasi sebesar US\$ 7,7 M di tahun 2001 yang seharusnya hanya US\$ 4,6 M. Sebelumnya, Worldcom melaporkan laba bersih sebesar US\$ 1,4 M dan US\$172 juta pada empat bulan pertama tahun 2002. Seharusnya mereka justru mengalami kerugian baik di tahun 2001 dan empat bulan pertama tahun 2002 jika biaya tersebut dialokasikan pada tahun yang bersangkutan. Di sini terjadi informasi yang sangat menyesatkan bagi pengguna laporan keuangan.

Analisis harga saham yang dihitung oleh fund manager dengan metode valuasi EV/EBITDA (enterprise value divided by Earning Before Interest Taxes Depreciation and Amortisation), sama seperti $\mathrm{P} / \mathrm{E}$ ratio, melaporkan bahwa EBITDA di tahun 2001 adalah US\$10,5 M padahal yang sebenarnya adalah hanya sekitar US\$ 6.3 M. Enterprise value adalah market capitalisation ditambah dengan hutang dan dikurangi kas. Misalkan dalam industri telekomunikasi EV/EBITDA multiple-nya berkisar sekitar 10x. Multiple ini akan digunakan untuk menilai harga wajar dari saham tesebut. Jadi jika Worldcom tidak mempunyai hutang, maka nilai perusahaan Worldcom mengunakan 10x multiple akan dihargai seharga US\$105 M, yang seharusnya adalah hanya sekitar US\$ $63 \mathrm{M}$ jika mengunakan standar akuntansi yang semestinya. Sehingga investor menghargai terlalu mahal harga saham Worldcom sebesar US\$42 milliar karena hasil creative accounting tesebut. Hal ini membuktikan bahwa accounting rules memiliki grey area, yang bisa dimanfaatkan oleh perusahaan yang tidak jujur.

Pandangan penulis dalam menyikapi alasan mengapa manajer melakukan creative accounting adalah manajer berusaha untuk bersikap hati-hati dalam mencoba untuk menghindari ketidakpastian siklus usaha di masa datang. Hal ini mengandung pengertian bahwa kegiatan operasi perusahaan yang sudah dicanangkan oleh 
perusahaan memberikan pandangan pesimistis bagi manajer dalam menghadapi situasi yang turbulence pada masa datang. Manajer bersikap demikian untuk mengantisipasi hasil kinerja yang dilakukannya berakibat buruk bagi penilaian evaluasi dirinya oleh manajemen. Akibatnya manajer bertindak oportunistik untuk melakukan berbagai macam cara agar kinerja manajer dapat stabil dalam periode pemantauan manajemen, diantaranya adalah creative accounting. Bagi manajer hal ini lazim. Creative accounting memberi manajer suatu kelenturan untuk melindungi dirinya dan perusahaan dalam mengantisipasi kejadian uncertainty. Siapa yang diuntungkan ? Pasti manajer dan perusahaan. Karena manajer terikat oleh kontrak dan dituntut untuk mencapai target perusahaan, maka manajer cenderung untuk mengejar kompensasi yang sudah diikat dalam kontrak. Layak bagi manajer untuk bersikap ego devensif karena hal ini dilakukan untuk menghindari kerugian dan merupakan penyesuaian sikap dalam melakukan konfirmasi kepada keputusan yang telah dibuat. Implikasinya creative accounting akan dikembangkan oleh manajer untuk mencapai apa yang diinginkannya dalam menghindari kerugian. Mengapa hal ini dilakukan? Proses creative accounting tercipta karena manajer menguasai informasi di perusahaan dan mengetahui kelemahan dan kekuatan dari peraturan-peraturan akuntansi yang bersifat sumir untuk memilih suatu kebijakan akuntansi. Karena transaksi didasarkan atas kebijakan akrual, maka bentuk ini menjadi sumber bagi manajer untuk mempermainkan, memanipulasi, dan merekayasa berbagai macam transaksi melalui transaksi buatan (artificial) sehingga dapat mempengaruhi dalam siklus akuntansi.

\section{Etika dalam Creative Accounting}

Laporan keuangan didasarkan pada hukum dan standar akuntansi. Pelanggaran terhadapnya adalah suatu serangan dan hukum mungkin dirubah. Pertimbangannya adalah ketiadaan semangat dari hukum karena hukum tidak pernah menjangkau secara pidana kepada pelaku, meskipun melihat keuangan sangat kompleks dan mempunyai seperangkat aturan yang ketat. Oleh karena itu, penciptaan creative accounting sangat memungkinkan dan banyak dilakukan walaupun secara moralitas hal tersebut banyak mengalami pelanggaran pada etika bisnis dan etika profesi.

Creative accounting merupakan tindakan yang dapat menyesatkan pemakai laporan keuangan dengan menyajikan informasi yang tidak akurat, dan bahkan kadang merupakan penyebab terjadinya tindakan ilegal, misalnya penyajian laporan keuangan yang terdistorsi atau tidak sesuai dengan sebenarnya serta salah saji secara material. Ditinjau dari sudut pandang etika, tindakan ini berarti pelangaran terhadap kepercayaan masyarakat. Revsine (1991) mempertimbangkan masalah dalam hubungan antara manajer dengan pemegang saham dan berpendapat bahwa problem menggambarkan keuntungan dari "penurunan" standar akuntansi yang menyediakan manajer dengan kebebasan dalam penentuan pelaporan dari income, mekanisme pasar akan melakukan secara efisien, pengidentifikasian prospek dari manipulasi akuntansi dan mencerminkannya dalam penentuan harga serta keputusan kontraktual. Hal ini 
menunjukkan etika yang bias dalam pemilihan kebijakan akuntansi yang ditinjau pada tingkatan makro dari peraturan akuntansi.

Sebaliknya Ruland (1984) memberikan pendapat berbeda. Dia memberikan pandangan antara tanggung jawab manajer yang positif dengan negatif. Secara positif, manajer mempunyai tugas menyajikan account yang tidak bias; dan secara negatif, manajer bertanggung jawab terhadap keadaan karena mereka gagal untuk mencegah. Revsine memandang etika dari sudut positif sedangkan Ruland melihat pandangan etika dari sudut negatif.

Merchant dan Rockness (1994) secara khusus menemukan bahwa ketika penyajian dengan skenario creative accounting, akuntan banyak mengkritik tentang penyalahgunaan aturan akuntansi daripada manipulasi transaksi. Sedangkan menurut Fischer dan Rosenzweig (1995), menunjukkan dua kemungkinan penjelasan untuk sikap akuntan. Pertama, akuntan akan memberi pendekatan berdasarkan aturan pada etika karena pengaruh pada pengguna laporan keuangan. Kedua, akuntan akan menyalah gunakan aturan akuntansi sebagai kegagalan dalam daerahnya, dan oleh karena itu banyak permintaan mereka mempertimbangkan etika, karena manipulasi transaksi gagal dalam wewenang manajemen serta bukan subjek untuk kesamaan kode etik. Temuannya adalah suatu perbedaan dalam sikap akuntan terhadap creative accounting tergantung pada motivasi dari manajemen.

Bagi profesi akuntan, creative accounting memberikan informasi yang menyebabkan pengguna laporan keuangan tidak menerima informasi yang wajar dan secara umum memandang hal tersebut sebagai etika yang meragukan karena akuntan sudah melanggar etika profesinya. Hal ini disebabkan penggunaan creative dalam laporan keuangan adalah suatu ilusi bagi entitas dengan membuat topeng realitas ekonomi melalui kesalahan aplikasi prinsip-prinsip akuntansi dan menyebabkan dampak yang luas terhadap aktivitas bisnis yang tidak fair.

Creative accounting merupakan tindakan yang tidak etis karena pelaksanaannya tidak didasarkan pada nilai-nilai kebenaran baik dari sisi cara, teknik, prosedur, maupun dari sisi tujuan yang akan dicapai. Profesi akuntan diatur dalam sebuah aturan yang disebut sebagai kode etik profesi akuntan. Dalam kode etik profesi akuntan ini diatur berbagai masalah, baik masalah prinsip yang harus melekat pada diri akuntan maupun melakukan komunikasi atau interaksi. Kode etik yang berkaitan dengan masalah prinsip bahwa auditor harus menjaga, menjunjung, dan menjalankan nilai-nilai kebenaran dan moralitas, seperti bertanggungjawab (responsibilities), berintegritas (integrity), bertindak secara objektif (objectivity) dan menjaga independensinya terhadap kepentingan berbagai pihak (independence), serta hati-hati dalam menjalankan profesi (due care).

\section{Solusi Dalam Menangani Creative Accounting}

Proses creative accounting akan menciptakan suatu pemilihan alternatif dari berbagai macam alternatif metode akuntansi yang telah diatur dalam standar akuntansi. Standar telah memberikan petunjuk bahwa apabila ada suatu event yang belum diatur dalam standar maka disarankan untuk merujuk pada general accepted 
accounting principle atau prinsip akuntansi yang berterima umum. Event inilah yang bagi pembuat laporan keuangan di manajemen memberikan suatu celah (loophole) yang akan bisa dilakukan proses perekayasaan laporan keuangan dalam berbagai bentuk. Dan ini bisa dikategorikan sebagai kosmetika akuntansi melalui manipulasi laporan keuangan.

Adanya fenomena tersebut yang berkaitan dengan kreativitas, maka berikut ini beberapa pemikiran untuk memberikan solusi bagaimana cara untuk mengatasi dan membendung creative accounting, meliputi: Pertama, masalah creative accounting berkaitan dengan berbagai macam alternatif pilihan metode akuntansi yang ditawarkan oleh standar akuntansi pada penerapannya di laporan keuangan. Sehingga mengatasi berbagai macam alternatif pilihan metode akuntansi adalah bagaimana mengembalikan alternatif pilihan metode akuntansi kepada standar akuntansi itu sendiri. Artinya, standar akuntansi memberikan kesempatan kepada manajemen untuk menggunakan, memilih, dan menerapkan metode tersebut sesuai dengan prinsip akuntansi. Dengan demikian, manajemen akan punya ruang gerak dan skope yang luas untuk mengkaji, menganalisis, dan menyajikan dalam laporan keuangan yang akan memberikan keuntungan bagi dirinya melalui proses perekayasaan. Sehingga dapat dikatakan manajemen bersikap opportunistic. Hal ini wajar dan sah saja karena manajemen akan mencari celah-celah aturan dalam standar yang lemah dan memberikan kontribusi untuk direkayasakan. Dengan demikian yang diperlukan adalah bagaimana melakukan review terhadap peraturan-peraturan akuntansi melalui standar akuntansi untuk selalu dilakukan pencarian peluang alternatif munculnya kelemahan-kelemahan dan ancaman serta alternatif munculnya kekuatan-kekuatan dalam metode akuntansi tersebut melalui proses hearing dalam dewan standar akuntansi ataupun melalui diskusi terbatas dalam kompartemenkompartemen di Ikatan Akuntan. Hasil ini akan memberikan solusi bahwa dengan munculnya kelemahan-kelemahan dan kekuatan-kekuatan dalam metode akuntansi, Ikatan Akuntan akan secara bijaksana dapat mengambil keputusan bahwa skope untuk memilih metode akuntansi akan berkurang melalui pengurangan jumlah metode akuntansi dari metode akuntansi yang diperkenankan atau melalui penentuan keadaan dalam tiap-tiap metode akuntansi yang digunakan.

Penetuan metode akuntansi akan memberikan pilihan yang positif bagi manajemen yaitu bilamana metode akuntansi sudah diatur dalam standar akuntansi dengan pilihan yang beragam dan dikembalikan lagi aturan tersebut kepada standar, maka akan memungkinkan dari regulator untuk memberikan petunjuk penggunaan metode akuntansi berdasarkan jenis perusahaan dan dimana lingkungan bisnis perusahaan tersebut berada. Sehingga manajemen akan memilih metode akuntansi yang sesuai dengan lingkungan bisnis perusahaan sehingga ketepatan pemilihan kebijakan akuntansi sangat tinggi dan penemuan kekuatan dan kelemahan metode tersebut akan mudah dikarenakan lingkungan bisnis perusahaan akan memberikan informasi ketepatan penyajian dan pelaporan keuangan dari dukungan kebijakan tersebut. Sedangkan bilamana metode akuntansi yang dianut tersebut belum diatur dalam standar akuntansi maka manajemen dapat berkiblat pada GAAP yang belum 
tentu semua pihak mengetahui aturan tersebut karena belum tertuang dalam standar akuntansi dan perbedaan persepsi dari penyaji dan pengguna. Hal ini akan memberikan pilihan negatif karena manajemen akan punya ruang gerak yang luas dan terdapat celah untuk memanfaatkan proses pilihan kebijakan dalam metode akuntansi dengan perekayasaan secara kreatif. Contohnya, penentuan penggunaan metode penilaian persediaan pada masa inflasi. Penentuan persediaan akan dihadapkan pada situasi nilai persediaan akan dilaporkan sebesar at cost, at sale, lower cost or market (lowcom), fair value, atau menggunakan general price level. Pada situasi kondisi dengan harga yang naik sangat tinggi, manajemen akan kontradiksi dengan kondisi nyata bila nilai persediaan dilaporkan dengan at cost dan lowcom serta akan selaras bila penentuan tersebut akan dilaporkan pada tingkat general price level atau fair value. Hal tersebut memberikan situasi yang kreatif bagi manajemen untuk menggunakan at sale, at cost, lowcom atau general price level.

Kedua, hasil penentuan metode akuntansi dari pengurangan berbagai alternatif metode akuntansi tersebut, dapat memberikan harapan ke depan bahwa penyajian dalam laporan keuangan akan memberikan kewajaran. Mengapa demikian? Ikatan Akuntan telah mampu mengatasi proses creative accounting dalam perekayasaan metode akuntansi melalui penentuan kelemahan dan kekuatan metode tersebut. Sehingga secara preventif, standar telah mempertimbangkan hasilnya bahwa hanya metode yang tepat untuk perusahaan dan industri tertentu saja yang dapat digunakan dalam proses akuntansi. Dan ini telah mengeliminasi peluang munculnya kelemahankelemahan yang akan rentan dalam perekayasaan. Dengan pola demikian, persyaratan konsistensi dari penggunaan metode akan membantu menghilangkan creative accouting, serta pemilihan metode tersebut akan menghasilkan potret perusahaan selama tahun tersebut yang akan berlanjut dan memaksa perusahaan tersebut untuk menggunakan metode yang sama pada keadaan masa yang akan datang. Implikasinya, manajemen tidak akan berhasrat untuk memainkan keuntungan dan cenderung melakukan secara wajar (fairness dan full disclosure) dan akan menaikkan the soundness of financial reporting system.

Hasil secara positif dari penentuan metode akuntansi adalah upaya bagi regulator untuk menaikkan the soundness of financial reporting system dalam pelaporan keuangan. Artinya, laporan keuangan akan menampilkan informasi yang wajar, bebas dari salah saji yang material, mengungkapkan secara penuh kejadiankejadian bisnis dengan benar, serta memberikan kandungan informasi yang berguna bagi pengguna untuk pengambilan keputusan.

Hasil negatif dari penentuan metode akuntansi adalah regulasi akan mempersempit ruang gerak dan loophole bagi akuntan manajemen dalam proses kreatif penggunaan metode akuntansi karena pilihan tersebut sudah diatur dalam standar akuntansi dan hukum berdasarkan lingkungan bisnis perusahaan. Sehingga pelanggaran bagi manajemen bilamana melakukan proses kreatif akan nampak dari pilihan yang diambil sebagai kebijakan yang tertuang dalam penyajian dan pelaporan keuangan berdasarkan spesifikasi jenis industri dan lingkungan bisnis perusahaan tersebut. Disamping itu, karena sifat oportunistik manajer akan menggali potensi 
pelaporan keuangan berdasarkan spesifikasi jenis industri dan lingkungan bisnis sebagai peluang dan kesempatan untuk melihat, menelusuri, dan mencari kelemahankelemahan dalam standar akuntansi dan hukum tersebut sebagai tempat dan ruang gerak mencari kembali proses kreatif akuntansi.

Ketiga, Ikatan Akuntan dalam Kompartemen Akuntan Manajemen (KAM) wajib membuat peraturan yang mengatur tentang syarat-syarat dari akuntan yang bekerja di perusahaan. Fokus utamanya adalah bahwa akuntan manajemen mempunyai integritas, prudent, due care, obyektifitas, dan mempunyai kompetensi. Disamping itu juga terdapat ketentuan tentang pengaturan sertifikasi bagi akuntan manajemen untuk memenuhi syarat-syarat diatas, artinya bahwa yang wajib membuat, menyajikan dan melaporkan serta bertanggung jawab dalam pembuatan laporan keuangan adalah akuntan manajemen yang bersertifikat (Bersertifikasi Akuntan Manajemen/BAM). Adanya aturan ini adalah sebagai tambahan untuk menyempurnakan peraturan sebelumnya. Ikatan Akuntan telah berusaha untuk menghilangkan faktor-faktor potensial yang akan meniadakan keakuratan informasi terutama dalam mekanisme proses pembuatan laporan keuangan. Sehingga diharapkan dengan sikap integritas, prudent, due care, obyektif, dan kompeten maka laporan keuangan akan bebas dari salah penyajian yang material, wajar, dan full disclosure. Kemungkinan bilamana diketahui ada indikasi munculnya creative accounting dalam laporan keuangan perusahaan berdasarkan hasil dari audit laporan keuangan auditor, maka Ikatan Akuntan Kompartemen Akuntan Manajemen berhak untuk melakukan pengendalian mutu atas laporan keuangan perusahaan tersebut jika auditor menyampaikan indikasi tersebut kepada Ikatan Akuntan KAM. Jika hasilnya positif, maka Ikatan Akuntan Kompartemen Akuntan Manajemen berhak untuk mencabut sertifikat akuntan manajemen untuk akuntan yang telah melakukan pelanggaran laporan keuangan melalui creative accounting. Hasil-hasil review pengendalian mutu kompartemen akuntan manajemen sebaiknya diinformasikan dalam media buletin akuntan manajemen untuk memberikan informasi antar sesama profesi dan pengguna sehingga memberikan implikasi bahwa perbuatan terlarang akan dapat mematikan karir seorang profesional di kemudian hari.

Hasil ini secara positif menunjukkan adanya perhatian IAI KAM dalam rangka menaikkan kepercayaan Akuntan Manajemen dimata pengguna untuk mempunyai sikap komitmen dan integritas yang tinggi pada derajat profesionalismenya. Proses sertifikasi tersebut menjadi bukti profesionelime akuntan manajemen mempunyai tanggung jawab dalam penyajian dan pelaporan keuangan yang bebas salah saji yang material. Secara negatif, adanya sertifikasi akuntan manajemen akan membuat proteksi bagi akuntan manajemen untuk bertindak secara luas. Artinya, akuntan yang belum mendapatkan sertifikasi akan merasa dirinya belum berkompetensi, belum mendapatkan pengakuan, dan keberpihakan pada perusahaan akan dipertanyakan.

Keempat, creative accounting dirancang oleh manajemen berdasarkan aspek pertimbangan-pertimbangan dari seluruh komponen di manajemen karena laporan keuangan tersebut mempertimbangkan kegunaannya untuk stakeholder, shareholder, 
dan manajer. Sehingga kepentingan berbagai macam tersebut harus dipenuhi terutama berdasarkan tujuan internal. Manajemen akan dengan opportunistic melihat kepentingannya untuk selalu ada pada prioritas utama. Karena adanya kontrak, maka manajemen akan berusaha untuk menunjukkan performancenya dalam kegiatan operasionalnya. Salah satu pengukurnya adalah laporan laba rugi. Disini, manajemen menunjukkan ada kecenderungan untuk memasukkan suatu "kerugian" atau "keuntungan" pada rekening extra-ordinary, dan memasukkan ke komponen tersebut adalah karena faktor pertimbangan. Hal ini sah bagi manajemen karena ketiadaan pengaturan penyajian dalam standar akuntansi. Untuk meminimalisasi kondisi ini, adalah bagaimana merancang suatu aturan yang dapat meminimalisasi penggunaan pertimbangan (justifikasi) untuk memasukkan suatu kejadian dalam pos extra ordinary. Hal ini cenderung dilakukan oleh akuntan perusahaan. Tetapi, disisi lain adanya ketiadaan aturan tersebut dalam standar akuntansi maka akuntansi memberikan jalan untuk berkiblat pada standar akuntansi berterima umum. Mekanisme ini merupakan loophole. Seharusnya standar akuntansi memuat kejadiankejadian yang bersifat dikotomi, artinya ada tempat untuk masuk sebagai kejadian operasional dan juga bisa masuk sebagai pos luar biasa. Keambiguan pos tersebut bisa diatasi dengan melihat kejadian tersebut dipengaruhi oleh faktor utama dari operasional atau dari kejadian luar biasa dari operasional atau kejadian luar biasa diluar faktor utama. Dengan alternatif-alternatif ini dan beberapa pendekatannya maka standar akuntansi dapat memberikan pemecahan-pemecahan yang luar biasa. Sehingga banyak kejadian-kejadian tersebut akan cenderung masuk sebagai kegiatan utama operasional perusahaan dalam operating profit.

Hasil ini secara positif akan memberikan peta kejadian utama asal peristiwa transaksi tersebut terjadi. Sehingga dengan pemetaan tersebut dapat memberikan implikasi pada operasi utama perusahaan ataukah pada operasi sampingan perusahaan ataukah pada peristiwa luar biasa dari perusahaan. Mekanismenya akan memberikan tuntunan peristiwa tersebut dapat dibebankan sebagai capital expenditure ataukah dibebankan sebagai revenue expenditure. Hal ini akan memberikan pengakuan dan pengukuran yang tepat bagi peristiwa-peristiwa tersebut. Secara negatif, pembebanan berdasarkan pertimbangan tersebut akan bersifat subyektif karena tiadanya aturan dalam pengakuan dan pengukuran, menyebabkan berbagai macam peristiwa akan diperlakukan dengan pertimbangan suka dan tidak suka. Contohnya, peristiwa adanya krisis moneter menyebabkan aktiva moneter terutama kewajiban jangka pendek dan kewajiban jangka panjang yang dinilai dengan satuan dollar akan menyebabkan nilai mata uang menjadi tinggi fluktuasinya. Sehingga menyebabkan perbedaan nilai mata uang yang sangat mencolok. Selisih nilai tukar antara nilai sekarang dengan nilai sebelumnya akan memberikan hasil yang tidak wajar.

Kelima, mendorong terciptanya standar etika. Standar etika tersebut memuat tentang mekanisme perilaku akuntan dalam pembuatan laporan keuangan. Isinya tentang perilaku etis mengenai hal-hal yang diperbolehkan dalam laporan keuangan dan hal-hal yang dilarang dalam perekayasaan laporan keuangan. Termasuk sangsi moral bilamana ada pelanggaran yang dilakukan oleh akuntan dalam perekayasaan 
laporan keuangan. Mengapa ini perlu ? Hal ini dikarenakan bahwa creative accounting merupakan tindakan pelanggaran karena pelaku melakukan perbuatan yang bersikap tidak etis dan melakukan tindakan yang dapat menyesatkan pemakai laporan keuangan dengan menyajikan informasi yang tidak akurat, dan bahkan kadang merupakan penyebab terjadinya tindakan ilegal, misalnya penyajian laporan keuangan yang terdistorsi atau tidak sesuai dengan sebenarnya. Akibatnya adalah pengguna akan mengambil tindakan pengambilan keputusan yang salah. Contohnya, di pasar modal. Harga saham akan mencerminkan seluruh informasi di pasar termasuk informasi laporan keuangan. Bilamana informasi laporan keuangan di pasar salah saji maka berimbas pada harga saham. Investor akan membeli saham pada harga yang tidak wajar karena tidak mencerminkan nilai fundamental perusahaan tentang value of the firm. Implikasinya, tindakan ini berarti pelangaran terhadap kepercayaan masyarakat. Masyarakat yang tidak percaya pada manajemen perusahaan tersebut akan lari dari perusahaan dan tidak bersikap responsif terhadap perusahaan tersebut.

Hasil ini secara positif menunjukkan peningkatan moral bagi akuntan manajemen untuk berperilaku etis dalam pembuatan laporan keuangan. Implikasinya bagi akuntan manajemen adalah berbuat baik dan bersikap jujur dalam pemenuhan sayart-syarat dan ketentuan dalam aturan sehingga menimbulkan aspek kepercayaan sebagai modal dasar yang akan mengalirkan keuntungan yang besar di masa depan. Secara negatif, sangsi moral yang diberikan akan memberikan ketidakpercayaan masyarakat kepda perusahaan tersebut. Akibatnya ada kemungkinan masyarakat profesi akan menjauhi hubungan profesi dengan perusahaan tersebut, kemungkinan produk tersebut dijauhi masyarakat karena high cost sehingga nilainya dibebankan kepada masyarakat, dan sebagainya.

Keenam, mendorong terciptanya governance codes, yaitu suatu sistem pemeriksaan dan keseimbangan yang melibatkan 3 bagian (parties) dalam perusahaan yaitu, manajemen, dewan direksi, dan pemegang saham untuk memainkan peran bagiannya dengan baik, sehingga 3 parties tersebut akan dapat melihat peran masingmasing bagian dan sebagai kontrol antar bagian sejauhmana tugas dan tanggungjawabnya dapat memberikan kontribusi dan integritasnya kepada manajemen, serta melakukan pencegahan atas seluruh ancaman yang dapat merugikan pihak-pihak di dalam dan diluar perusahaan. Contoh, adanya pemisahan peran antara pemegang saham sebagai prinsipal dengan manajer sebagai agennya, maka manajer pada akhirnya akan memiliki hak pengendalian yang signifikan dalam hal bagaimana mereka mengalokasikan dana investor. Selain itu, dewan merupakan pusat dari pengendalian dalam perusahaan, dan dewan ini merupakan penanggung jawab utama dalam tingkat kesehatan dan keberhasilan perusahaan secara jangka panjang. Dewan direksi dalam suatu perusahaan akan menentukan kebijakan yang akan diambil atau strategi perusahaan tersebut secara jangka pendek maupun jangka panjang. Sedangkan peran dewan komisaris dalam suatu perusahaan lebih ditekankan pada fungsi monitoring dari implementasi kebijakan direksi. Peran komisaris ini diharapkan akan meminimalisir permasalahan agensi yang timbul antara dewan 
direksi dengan pemegang saham. Oleh karena itu dewan komisaris seharusnya dapat mengawasi kinerja dewan direksi sehingga kinerja yang dihasilkan sesuai dengan kepentingan pemegang saham.

Hasil ini secara positif adalah cukup efisien untuk mengatasi masalah keagenan karena dengan governance codes akan terjadi suatu sistem untuk mengarahkan (direct) dan mengendalikan (control) suatu perusahaan/korporasi sehingga memberikan manfaat dalam bentuk dipercayainya perusahaan oleh investor, mitra bisnis ataupun kreditor; menjadi lebih linear karena pembagian tugas serta kewenangan yang jelas; perimbangan kekuatan diantara struktur internal perusahaan, yakni direksi, komisaris, komite audit dan sebagainya; pengambilan keputusan menjadi lebih akuntabel dan lebih berhati-hati demi sustainability perusahaan. Implikasinya, Governance codes akan memberikan keyakinan pada stakeholder dan perusahaan akan diperolehnya return atas investasi mereka. Secara negatif, perusahaan didirikan dengan tujuan meningkatkan nilai perusahaan melalui peningkatan kemakmuran pemilik atau para pemegang saham. Namun dilain pihak manager sebagai pengelola perusahaan mempunyai tujuan yang berbeda terutama dalam hal peningkatan prestasi individu dan kompensasi yang akan diterima. Jika manager perusahaan melakukan tindakan-tindakan yang mementingkan diri sendiri dengan mengabaikan kepentingan investor, maka akan menyebabkan jatuhnya harapan para investor tentang pengembalian (return) atas investasi yang telah mereka tanamkan.

\section{SIMPULAN}

Creative accounting timbul karena perusahaan harus berada dalam posisi laba untuk menarik stakeholder. Akibatnya, manajemen membuat suatu tindakan yang mengarah pada perilaku oportunistik yaitu kosmetika akuntansi melalui tindakan accounting policy, earning management, income smoothing, manipulasi laporan keuangan, serta fraud pada praktik akuntansi. Creative accounting dikatakan ilegal apabila memang ternyata sudah menyalahi prosedur atau perundang - undangan yang berlaku melalui "LOOPHOLE" dalam peraturan itu sendiri. Pencegahan yang mendasar dan utama terhadap creative accounting bagi akuntan manajemen dapat dilakukan dengan meningkatkan moralitas dan etika dengan memahami bahwa suatu tindakan creative accounting adalah salah, ilegal, dan tidak etis.

Solusi untuk menangani masalah creative accounting dapat dilakukan dengan berbagai cara berikut ini, yaitu mengembalikan alternatif accounting policy kepada standar akuntansi, review kebijakan akuntansi, sertifikasi akuntan manajemen, eliminasi justifikasi penggunaan extra ordinary atas transaksi, mendorong terciptanya standar etika bagi akuntan manajemen, mendorong terciptanya governance codes dalam tata kelola perusahaan. Implikasinya, apabila cara-cara menangani creative accounting tersebut dilaksanakan, maka distorsi dalam laporan keuangan akan terwujud sehingga salah saji yang material akan dapat dihindari. 


\section{DAFTAR PUSTAKA}

Amat, Oriol, Blake, John, and Dowd, Jacks, 1999, The Ethics of Creative Accounting, Economics Working Paper, SSRN, December

Bapepam, Kasus PT Kimia Farma Tbk, Siaran Pers Bapepam, 27 Desember 2002

Bapepam, Kasus PTBank Lippo Tbk, Siaran Pers Bapepam, 27 Desember 2002

Ferdinand Sadeli dan Ferry Wong, 2004, Creative Accounting : Kasus Worldcom, Financial, Investment, and Business Excellence.

Fischer, M., and Rosenweig, K., 1995, Attitudes of Students and Accounting Practitioners Concerning The Ethical Acceptability of Creative Accounting, Journal of Business Ethics, 14, pp. 433-444.

Merchant, K.A., and Rockness, J., 1994, the Ethics of Managing Earnings: an Empirical Investigation, Journal of Accounting and Public Policy, 13, pp. 7994.

Naser, K, 1992, A Note on the use of Creative Accounting, British Accounting Review, 24, pp. 111-118.

Revsine, L., 1991, The Selective Financial Misrepresentation Hypoyhesis, Accounting Horizons, December, pp. 16-27.

Ruland, R.G., 1984, Duty, obligation and Responsibility in Accounting Policy Making, Journal of Accounting and Public Policy, Fall, pp. 223-237.

Slovic, Paul, 1995, The Construction of Preference, Journal American Psychologist, pp. 364-371.

Tempo Interaktif, Kimia Farma Lakukan Kesalahan Pencatatan Laporan Keuangan, 3 Oktober 2002 